\title{
Outmigration survival of wild Chinook salmon smolts through the Sacramento River during historic drought and high water conditions
}

\author{
Jeremy J. Notch $\mathbb{D} \cdot$ Alex S. McHuron • \\ Cyril J. Michel • Flora Cordoleani • Matt Johnson • \\ Mark J. Henderson • Arnold J. Ammann
}

Received: 8 August 2019 / Accepted: 20 January 2020 /Published online: 27 January 2020

(C) The Author(s) 2020

\begin{abstract}
Populations of wild spring-run Chinook salmon in California's Central Valley, once numbering in the millions, have dramatically declined to record low numbers. Dam construction, habitat degradation, and altered flow regimes have all contributed to depress populations, which currently persist in only a few tributaries to the Sacramento River. Mill Creek (Tehama County) continues to support these threatened fish, and contains some of the most pristine spawning and rearing habitat available in the Central Valley. Despite this pristine habitat, the number of Chinook salmon returning to spawn has declined to record low numbers, likely due to poor outmigration survival rates. From 2013 to 2017, 334 smolts were captured and acoustic tagged while outmigrating from Mill Creek, allowing for movement and
\end{abstract}

\footnotetext{
J. J. Notch $(\bowtie) \cdot$ A. S. McHuron · C. J. Michel •

F. Cordoleani

Affiliated with Southwest Fisheries Science Center, National Marine Fisheries Service, NOAA, University of California Santa Cruz, 110 McAllister Way, Santa Cruz, CA 95060, USA e-mail: jeremy.notch@noaa.gov
}

\section{Johnson}

California Department of Fish and Wildlife, 1530 Schwab Street, Red Bluff, CA 96080, USA

\section{J. Henderson}

U.S. Geological Survey, California Cooperative Fish and Wildlife Research Unit, Department of Fisheries Biology, Humboldt State University, Arcata, CA, USA

\section{A. J. Ammann}

Southwest Fisheries Science Center, National Marine Fisheries Service, NOAA, 110 McAllister Way, Santa Cruz, CA 95060, USA survival rates to be tracked over $250 \mathrm{~km}$ through the Sacramento River. During this study California experienced both a historic drought and record rainfall, resulting in dramatic fluctuations in year-to-year river flow and water temperature. Cumulative survival of tagged smolts from Mill Creek through the Sacramento River was 9.5\% $( \pm 1.6)$ during the study, with relatively low survival during historic drought conditions in 2015 $(4.9 \% \pm 1.6)$ followed by increased survival during high flows in 2017 (42.3\% \pm 9.1). Survival in Mill Creek and the Sacramento River was modeled over a range of flow values, which indicated that higher flows in each region result in increased survival rates. Survival estimates gathered in this study can help focus management and restoration actions over a relatively long migration corridor to specific regions of low survival, and provide guidance for management actions in the Sacramento River aimed at restoring populations of threatened Central Valley spring-run Chinook salmon.

Keywords Acoustic telemetry - Salmon survival · Sacramento River · Chinook salmon · Biotelemetry Central Valley

\section{Introduction}

Wild stocks of spring-run Chinook salmon (Oncorhynchus tshawytscha) were abundant in all rivers draining into California's Central Valley (CCV) prior to dam construction, with population estimates of over two million spawning adults (Yoshiyama et al. 1998). Many 
of these populations have since been extirpated, due in large part to the loss of $47 \%$ of historic spawning and rearing habitat behind large impassable dams (Yoshiyama et al. 2001). For the past few decades, annual run sizes of remaining populations have been around $1 \%$ of the estimated historic average (Yoshiyama et al. 2001; Williams et al. 2016). The remaining populations of wild spring-run Chinook salmon in the CCV are isolated to just a few tributaries to the Sacramento River, with self-supporting populations limited to Deer, Mill and Butte Creeks (NMFS 2014). In these tributaries, access to pristine spawning and rearing habitat persists, and spatial segregation restricts inter-breeding with hatchery-origin fall-run Chinook salmon. Despite the pristine spawning and rearing habitat, these populations have declined severely, and in 1999 the CCV spring-run Chinook salmon Evolutionary Significant Unit was listed as threatened under the federal Endangered Species Act.

The downstream migration of smolts to the ocean is considered a highly vulnerable phase in the Pacific salmon life cycle, accounting for a high proportion of mortality over a short window of time (Healey 1991; Bradford 1995; Rechisky et al. 2012; Clark et al. 2016). It is presumed that the declining populations of wild salmon in the CCV are a result of the modified river and estuary environment that has reduced rearing potential (Sommer et al. 2001), increased predation risks (Grossman 2016), and limited available natural riparian habitat (Moyle et al. 2007). Increased predation risks are due to non-native species introductions and altered flow and temperature regimes in the Sacramento River and Delta that together have increased the vulnerability of juvenile salmon to both native and non-native predators (Nobriga 2007; Cavallo et al. 2012). Without significant habitat improvements in the river and estuary environments, as well as improved instream flows, the negative effects of altered outmigration habitats on CCV Chinook salmon smolts will likely intensify as the climate in California becomes more extreme as a consequence of anthropogenic climate change (Yates et al. 2008).

Extant populations of CCV spring-run Chinook salmon exhibit diverse life-history strategies characterized by large variations in size, timing, and age during outmigration from natal tributaries. One strategy is characterized by prolonged tributary rearing until the onset of smoltification, followed by rapid outmigration through the riverine and estuarine environments to the ocean during late spring (Johnson and Merrick 2012).
Compared to other populations of CCV Chinook salmon, tributary spring-run Chinook salmon juveniles have slow growth rates and delayed outmigration timing resulting from low water temperatures in high elevation rearing habitat (Johnson and Merrick 2012). This delay in growth and outmigration timing often results in exposure to low flows and elevated water temperatures in the mainstem Sacramento River, which is largely diverted during the spring for agricultural water uses.

Water storage in Shasta Reservoir and surface water diversions downstream have significantly altered the hydrograph of the Sacramento River, primarily by reducing peak flows during the winter and spring and truncating the recession limb of spring snowmelt events (SWRCB 2017). Historically these flow events triggered smolt outmigration to the ocean, but today smolts experience increasingly diminished stream flow during the spring because of the cumulative impacts of water diversions. Water releases from Shasta Dam are tightly managed to meet a variety of objectives that include deliveries for State and Federal water projects, managing salinity levels in the Delta, and preserving coldwater in Shasta Reservoir to protect incubating endangered winter-run Chinook salmon eggs below the dam. As a result, median flows in the Sacramento River during March and April are less than 50\% of unimpaired flow (SWRCB 2017), which can lead to decreased turbidity levels and elevated water temperatures, both of which have negative impacts on smolt survival (Becker 1971; Gregory 1993; Baker et al. 1995; Cavallo et al. 2012).

Several studies have focused on hatchery smolt survival in the $\mathrm{CCV}$, with all finding low outmigration survival rates to the ocean compared to studies conducted in the Columbia and Fraser rivers in the Pacific Northwest region of the United States and Canada (Brandes and McLain 2001; Welch et al. 2008; Buchanan et al. 2013; Michel et al. 2015). However, insufficient data exists on the survival rates of wild Chinook salmon smolts in the CCV, primarily due to the difficulty in capturing these rare fish. Wild salmon smolts out-migrate to the ocean across many weeks during the spring compared to hatchery-origin salmon (Sturrock et al. 2019), which are typically released in a few large groups. Inferring survival rates for wild smolts based on acoustic tagged hatchery salmon can be misleading due to differences in fish size, behavior, fitness, and environmental conditions encountered while outmigrating. Thus, understanding the movement and 
survival rates of wild smolts across contrasting water year types is needed to devise effective management strategies for recovering wild spring-run Chinook salmon populations.

In this study, we measured the movement and survival rates of acoustic tagged wild Chinook salmon smolts from Mill Creek, a tributary to the upper Sacramento River which supports some of the last remaining wild spring-run Chinook salmon in the CCV. Utilizing detection data from an extensive network of acoustic receivers, we calculated the movement and survival rates of acoustic tagged juvenile salmon at fine spatial scales throughout Mill Creek and the Sacramento River. We used data collected over five consecutive years (2013-2017) to estimate survival and movement rates over a range of environmental conditions. Most notably, three consecutive years of drought followed by an extremely wet year provided us with insight into the relationship between environmental conditions and outmigration survival of wild salmon smolts in the CCV.

\section{Methods}

Study area

Originating in Lassen National Park, Mill Creek flows south-west through protected land in Lassen National Forest and into a remote canyon with limited public access. Mill Creek is $100 \mathrm{~km}$ long and originates at $2000 \mathrm{~m}$ in elevation, providing salmon and steelhead access to some of the highest elevation anadromous fish spawning habitat in the United States. Upon reaching the valley floor, water from Mill Creek is diverted from April through October for agricultural purposes behind two small dams, both of which provide anadromous fish upstream access with fish ladders. This study focuses on the movement and survival rates of wild juvenile salmon smolts captured, tagged and released below the upstream diversion dam on Mill Creek and extends downstream to the lower Sacramento River (Fig. 1).

Mill Creek joins the Sacramento River, the largest river in California draining an area of $70,000 \mathrm{~km}^{2}$, at river kilometer 441 (distance upstream from ocean $\mathrm{rkm}$ ). The Sacramento River begins at Shasta Dam near the northern end of the CCV, and flows for $289 \mathrm{rkm}$ downstream of Mill Creek before transitioning into the Sacramento-San Joaquin River Delta, which transitions into the San Francisco Estuary and finally the Pacific
Ocean at the Golden Gate Bridge. The Sacramento River has two distinct regions, noted as the upper (rkm 441-344) and lower (rkm 344-203) Sacramento River in this study (Fig. 1). The upper Sacramento River is in a relatively natural state, containing expansive gravel bars, riparian habitat and large woody debris, whereas the lower Sacramento River is highly modified for agricultural purposes and channelized by levees. The Sacramento River is impacted in both regions by water diversions, which divert increasingly more water in lower reaches to supply neighboring agricultural fields.

Fish collection and tagging

Approximately $10 \mathrm{~km}$ upstream from the Sacramento River and directly below the upper diversion dam on Mill Creek, a rotary screw trap (RST) was used to capture migrating salmon smolts. The location is below much of the juvenile rearing habitat for spring-run Chinook salmon, and the smolts captured here are more likely to be actively migrating downstream to the ocean. The $1.5 \mathrm{~m}$ diameter RST was deployed in early April each year and operated continuously until catch rates diminished due to cessation in outmigration as a result of elevated water temperatures and decreasing flows (typically late May to early June). The trap was checked daily for juvenile salmon, which were netted and placed in holding buckets before being weighed to the nearest tenth of a gram and measured to the nearest $\mathrm{mm}$ of caudal fork length. All salmon of appropriate size were anesthetized in MS-222 buffered with $120 \mathrm{mg} \cdot \mathrm{L}^{-1}$ sodium bicarbonate prior to surgery the morning of capture, which involved implanting acoustic transmitters (tags) into the coelomic cavity of the anesthetized fish (Deters et al. 2010). Fish were selected to prevent tag weight from exceeding 5\% of the fish's body weight, which previous research has found to be an acceptable level of burden in survival studies (Brown et al. 2010; Ammann et al. 2013). This guideline suggested that smolts as small as $6 \mathrm{~g}$ and $80 \mathrm{~mm}$ fork length could be acoustic tagged with the transmitter used in this study without significant negative effects.

During 2013-2014, fish were released in Mill Creek below the RST approximately $1 \mathrm{~h}$ after recovery from anesthesia. Because these smolts were actively migrating, releasing them soon after recovery was considered the best option to avoid additional stress and disruption of their migratory inclination. Beginning in 2015, we modified the release procedure after low survival rates 


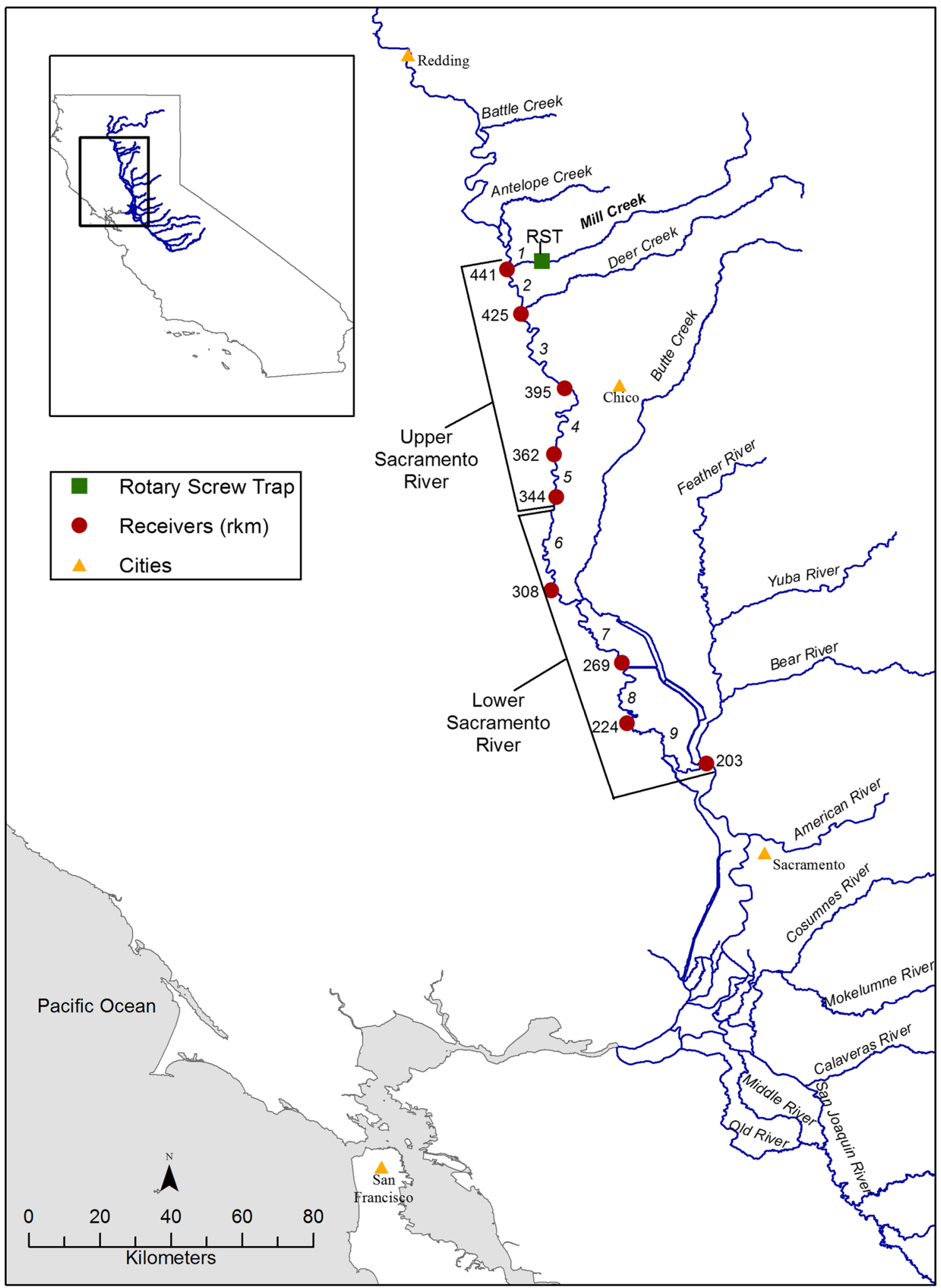


Fig. 1 Location of each region used for this study (Mill Creek, upper Sacramento River, lower Sacramento River). Red dots indicate the location of an acoustic receiver, numbers next to red dots indicate the river kilometer, numbers between red dots indicate the reach number, and the green square indicates the tagging and release site in Mill Creek. The second diversion dam in Mill Creek is located between the RST and the first red dot

were observed within Mill Creek in 2014, and employed an automated release cage for the remainder of the study. This floating device $(30 \mathrm{~cm}$ wide $\times 60 \mathrm{~cm}$ high $\times 50 \mathrm{~cm}$ long) fabricated of aluminum panels with $0.2 \mathrm{~cm}$ diameter holes allowed smolts to rest in shade throughout the day before a battery powered door opened at 22:00, and potentially reduced the risk of predation while outmigrating at night. The release cage also allowed us to observe the behavior of tagged smolts over a period of time, which a recent study suggests becomes normal after $24 \mathrm{~h}$ post-surgery (Singer et al. 2019). All tagged fish in this study appeared to be in good condition, and no mortalities were observed prior to release, however, the change in release strategy could potentially have influenced survival rates after the release cage was used in 2015.

Due to the tag-related restrictions in fish size, smolts used for this study are representative of the larger size class out-migrating from Mill Creek during the spring. The historic median size (1995-2010) of juveniles captured in the RST during the study period was $68 \mathrm{~mm}$, with the tagging size threshold of $80 \mathrm{~mm}$ representing the 80th percentile (Johnson and Merrick 2012). As a result, the smolts in this study may exhibit different migration characteristics and survival rates compared to the smaller size classes of juveniles out-migrating from Mill Creek during the same time period.

\section{Acoustic telemetry}

We used the Juvenile Salmon Acoustic Telemetry System (JSATS) to track survival and movement rates of juvenile Chinook salmon (McMichael et al. 2010). The JSATS uses tags that emit a unique ID at $416.7 \mathrm{kHz}$. Tags were programmed to transmit at a five second interval, enabling the tag to function for a minimum of 27 days. The tags used in 2013 were Lotek Wireless model L-AMT-1.416 with a weight in air of $280 \mathrm{mg}$ and dimensions of $10.5 \mathrm{~mm}$ long $\times 5.2 \mathrm{~mm}$ high $\times 3.0 \mathrm{~mm}$ wide. Tags used in 2014-2017 were Advanced Telemetry Systems (ATS) model SS300 with a weight in air of $300 \mathrm{mg}$ and dimensions of $10.7 \mathrm{~mm}$ long $\times 5.0 \mathrm{~mm}$ high $\times 2.8 \mathrm{~mm}$ wide. The transmissions from the tags were detected and recorded by autonomous receivers from different manufacturers (ATS, Teknologic, and Lotek Wireless). Most receiver locations had two receivers to maximize detection probability.

Each year over 140 acoustic receivers were deployed throughout the migration pathway for juvenile Chinook salmon from Mill Creek to the Pacific Ocean; however for the purposes of this study, receivers from the Delta and San Francisco Bay were excluded, and the focus area was from release at Mill Creek to the lower Sacramento River at the Feather River confluence. Within Mill Creek, the upper Sacramento River and lower Sacramento River, smaller reaches were separated within each region (Fig. 1). Reaches were selected by dividing relatively long segments of river into smaller sections $(20-30 \mathrm{~km})$, which allowed movement and survival rates to be analyzed at smaller distances and indicated specific areas of low survival rates over time. The receivers were left in place for 30 days after the last smolt was tagged and released each year.

\section{Data analysis}

To estimate reach, regional, and cumulative survival, we used a Cormack-Jolly-Seber (CJS) model for live recaptures (Cormack 1964; Jolly 1965; Seber 1982) using program MARK (White and Burnham 1999) within the RMark package (Laake and Rexstad 2013) in R statistical software, version 3.3.0 (R Core Team 2016). A spatial adaptation of the CJS model works well for juvenile Chinook salmon which tend to exhibit a strict downstream movement behavior once smoltification has begun (Healey 1991). This behavior is advantageous for acoustic telemetry studies in riverine environments due to the linear nature of these systems, which require the fish to pass through specific reaches. As the tagged fish were migrating toward the ocean, we assumed that if no detections were recorded downstream of its last detection, the fish died between its last detection and the next downstream receiver. In addition, we assumed tags remained inside the fish for the duration of the study and were not expelled, as previous research shows tag shedding does not occur for at least 10 days (Notch 2017), which is after fish would have transited the study area.

When calculating survival rates, we also considered detection probability of the receivers (probability of detecting a passing acoustic tag), which can introduce 
error under certain environmental conditions. The noise caused by high water flows can impair receiver efficiency, increasing the likelihood of fish passing undetected, and contributing to overall uncertainty. To calibrate these estimates, the CJS model takes into account fish detected at downstream receivers to estimate the proportion of fish that were detected while moving past the upstream receiver's location, and then uses maximumlikelihood estimates for detection probability of all monitoring locations (p), all apparent survival estimates $(\Phi)$, and $95 \%$ confidence intervals for both (Lebreton et al. 1992). With the exception of 2015 , we had relatively small sample sizes throughout this study, which led to increasing uncertainty in survival estimates from upstream to downstream, as fewer fish remained in the system.

\section{Cumulative survival}

To calculate cumulative survival within each region and through the study area, the raw (un-standardized) reach-specific survival estimates were multiplied within the region of interest. To account for the propagation of error, standard errors of the cumulative products of survival were calculated using the deltamethod.special function within the RMark package (Seber 1982; Powell 2007). This function requires the variance-covariance matrix for the cumulative survival estimates, and approximates the standard errors for the cumulative products of survival using a first-order Taylor approximation.

\section{Regional survival}

To calculate the regional survival rates, we simplified the pathway by using three reaches (regions) for the model; Mill Creek (reach 1, rkm 450-441), the upper Sacramento River (reach 2-5, rkm 441-344) and the lower Sacramento River (reach 6-9, rkm 344-203). We chose these regions based on their distinct habitat types and flow values resulting from water diversions that remove increasingly more water in lower reaches. We created a capture history matrix by assigning a 1 to fish detected within each region or farther downstream, and a 0 to fish not detected at the end of each region or farther downstream. Within the reach specific and regional survival analysis, we first estimated survival rates using a fully-parameterized survival and detection probability model that included no environmental covariates.
Reach-specific survival

Reach-specific survival estimates were calculated using all nine reaches in the study from Mill Creek through the upper and lower Sacramento River (rkm 450-203). We standardized survival rates per $10 \mathrm{~km}$ in order to compare estimates among reaches of varying distances (hereafter referred to as survival rates). We created a capture history matrix for all tagged fish by compiling detections at each receiver site into a 1 (detection) or 0 (no detection), allowing the CJS model to calculate survival rates and detection efficiencies for each reach within each year. Survival estimates in the final reach were generated by compiling detections in reaches downstream of the study area, which allowed for the estimation of detection probability at the final receiver line. The resulting survival rates represent the mean estimates for each reach or region, plus and minus the standard error.

\section{Covariate survival}

Several covariates were considered in an effort to determine which individual and environmental factors were most influential in regional smolt survival. We chose covariates that are believed to be strong drivers of smolt survival: streamflow (Raymond 1968; Connor et al. 2003; Tiffan et al. 2009), water temperature (Baker et al. 1995; Sykes et al. 2009), turbidity (Gregory 1993; Gregory and Levings 1998) and fish size (Munsch et al. 2019). Specifically, we considered Mill Creek flow at fish release [cubic feet per second (CFS)], Mill Creek temperature at fish release (degrees Celsius), upper Sacramento River flow (CFS), lower Sacramento River flow (CFS), lower Sacramento River temperature (degrees Celsius), lower Sacramento River turbidity (Nephelometric Turbidity Unit (NTU)), and fish length $(\mathrm{mm})$. We used environmental data from state and federal streamflow gauges, and assigned specific values to each fish according to the time they entered each region. For individual fish that were not detected entering the upper Sacramento River region but detected further downstream, we estimated entry time by adding the average Mill Creek travel time estimate to the release time. For individual fish that were not detected entering the lower Sacramento River region but detected farther downstream, we estimated the entry time as the average upper Sacramento River travel time added to the actual or estimated entry time into the upper Sacramento River 
region. We assessed the influence of individual and environmental covariates factors on survival by allowing each fish to have its own set of covariate estimates based on the in-situ water conditions encountered in each region.

We included all covariates in a suite of survival models using every possible combination of environmental and individual covariates, which we then compared to other non-covariate survival models: a null model (constant survival through space and time) and a base model (reach). We compared models for fit using Akaike's Information Criterion, with a correction for small sample sizes (AICc) (Akaike 1981). This criterion ranks each model by assigning a score according to how accurate the model is relative to the given data, and penalizes models with many parameters. To determine the rank of the different models, we used the difference in AICc score relative to the top model ( $\triangle \mathrm{AICc}$ ). For models with $\triangle \mathrm{AICc}<2$, we selected the model with the fewest parameters as the best model (Burnham and Anderson 2002). If more than one model was selected using this procedure, we used model averaging to estimate model parameters and standard errors (Burnham and Anderson 2002).

In total, we used 256 models in the survival analysis, testing all possible combination of reach plus individual and environmental covariates. Within program MARK, survival was modeled as a function of reach length and a number of individual and environmental parameters (Eq. 1), while detection efficiency varied by reach and year. One parameter coefficient $(\beta)$ for each environmental and individual variable quantifies the linear relationship between that variable and survival. By standardizing the environmental and individual covariates (subtracting the mean value from each raw data point and dividing by the standard deviation), resulting standardized beta coefficients offer a straightforward interpretation across different models and environmental covariates. For a change in one standard deviation of the environmental variable, survival will change by the amount specified by that model's standardized beta coefficient. Eq. 1 shows the formulation of the survival model used:

$$
\begin{aligned}
\operatorname{Logit}(\Phi)= & \beta_{0}+\beta_{1}[\text { Reach Length }] \\
& +\beta_{2}[\text { Env.Variable } 1]+[\ldots] \\
& +\beta_{(V+1)}[\text { Env.Variable } V]
\end{aligned}
$$

where $\beta_{0}$ is the intercept, and $V$ is the number of environmental covariates in any given model.

Once we selected the top covariate model, we predicted the effects of covariates on survival across the range of values observed during this study in each study region using model parameter estimates. This analysis allowed for an interpretation of the effect that each covariate may have on survival across a range of environmental conditions. The survival predictions are also bounded by $95 \%$ confidence intervals, which increase at the upper values of environmental parameters as a result of the small sample size experiencing those conditions.

\section{Results}

We tagged a total of 334 smolts during five years (20132017), with inter-annual variation in the sample sizes and forks lengths. The mean tagged fish fork length ranged from $83.5 \mathrm{~mm}$ to $86.9 \mathrm{~mm}$ and varied significantly among years $(P=0.02)$. Fish weight was more consistent, ranging from $6.7 \mathrm{~g}$ to $7.7 \mathrm{~g}$, which did not vary significantly among years $(P=0.24)$. Sample sizes of tagged smolts were relatively small for years 2014 , 2016 and $2017(n=23-36$; Table 1) due to limited numbers of juvenile salmon present in Mill Creek (likely due to low numbers of spawning adult salmon the prior year). Additionally, many captured fish were not tagged due to the $\geq 80 \mathrm{~mm}$ and $6 \mathrm{~g}$ minimum tagging size threshold.

Due to severe drought conditions in three of the five years of this study $(2013,2014,2015)$, study-period flows were lower and water temperatures higher in Mill Creek during drought years relative to the 20 year average (Fig. 2). Mill Creek flows increased considerably in 2016-2017 resulting from above average snowpack in

Table 1 Sample size, weight and length for smolts tagged and released each year

\begin{tabular}{llll}
\hline Year & Sample Size & Fork Length \pm SD $(\mathrm{mm})$ & Weight \pm SD $(\mathrm{g})$ \\
\hline 2013 & 59 & $84.2 \pm 11.4$ & $7.3 \pm 3.3$ \\
2014 & 36 & $83.5 \pm 2.9$ & $6.7 \pm 0.9$ \\
2015 & 186 & $86.9 \pm 6.2$ & $7.4 \pm 2.1$ \\
2016 & 23 & $85.7 \pm 4.0$ & $7.7 \pm 1.1$ \\
2017 & 30 & $86.1 \pm 4.4$ & $7.4 \pm 1.3$ \\
ALL & 334 & $85.9 \pm 7.1$ & $7.4 \pm 2.1$ \\
\hline
\end{tabular}




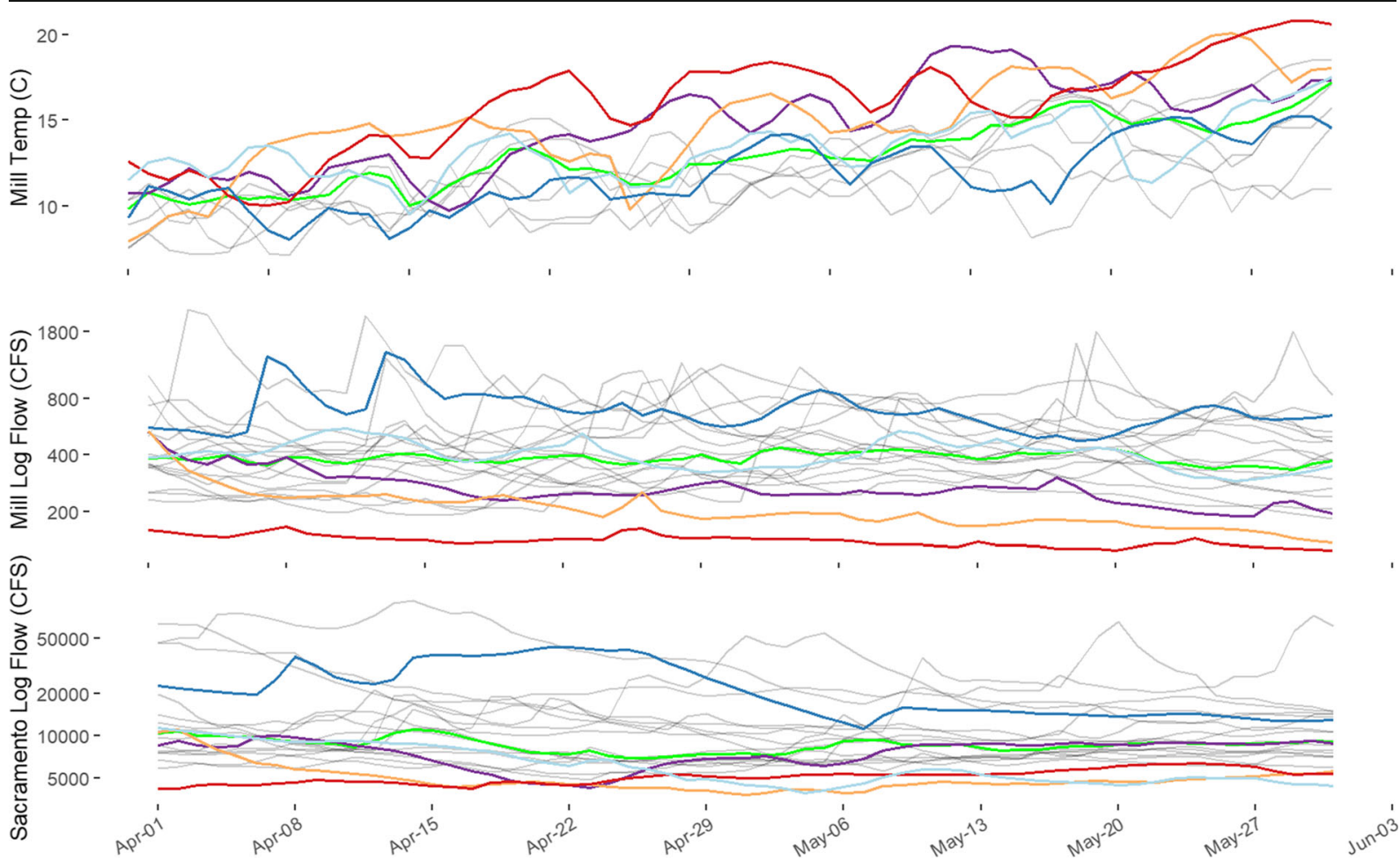

Fig. 2 Mill Creek temperature (top), flow (middle), and Sacramento River flow at Butte City (bottom) from 1998 to 2017 (grey lines). The green line is the 20 year median, purple line is 2013, orange line is 2014 , red line is 2015 , light blue line is 2016 , and dark blue line is 2017

both years and record rainfall in 2017. Drought conditions also influenced Sacramento River flows during this study, with four of the five years (2013-2016) having considerably lower flows compared to the 20year average (Fig. 2). In addition, water diversions for agricultural practices coinciding with this study further reduced Sacramento River flows in lower reaches. Sacramento River flows increased in 2017 relative to the 20 -year average, resulting from an extremely wet winter and spring.

\section{Cumulative survival}

Fish exhibited variable cumulative survival from Mill Creek through the Sacramento River, ranging from $0 \%$ in 2016 to $42.3 \%( \pm 9.1)$ in 2017 (Table 2), with a mean survival of $9.5 \%( \pm 1.6)$. With the exception of 2016 , cumulative survival through the upper Sacramento River ranged from $73.3 \%( \pm 6.1)$ in 2017 to $27.9 \%( \pm 3.8)$ in 2015 , and cumulative survival through the lower Sacramento River ranged from $61.3 \%( \pm 7.9)$ in 2017 to $15.3 \%( \pm 4.5)$ in 2015 .

\section{Regional survival}

Region specific survival rates were relatively consistent among years in the upper and lower Sacramento River, but varied annually within Mill Creek (Fig. 3). Survival rates in Mill Creek ranged from $88.1 \%( \pm 3.0)$ in 2017 to $62.1 \%( \pm 3.1)$ in 2015. With the exception of 2016, survival rates in the upper Sacramento River ranged from $96.5 \%$ ( \pm 0.9 ) in 2017 to $86 \%( \pm 1.4)$ in 2015 , and survival rates in the lower Sacramento ranged from $98.1 \%( \pm 0.7)$ in 2017 to $92.0 \%( \pm 2.3)$ in 2015 . The small sample size in 2016 did not allow for the calculation of survival estimates in the Sacramento River that year.

\section{Reach-specific survival}

Reach specific survival rates averaged among all years followed a similar pattern to the regional survival rate. The lowest survival rates were observed in Mill Creek (reach $1 ; 67.9 \% \pm 2.6$ ), followed by the highest survival rates in the first upper Sacramento River reach (reach 2; $97.5 \% \pm 0.9$ ), and progressively lower survival rates in 
Table 2 Survival rates (per $10 \mathrm{~km}$ ) and cumulative survival for each study region per year, including cumulative survival through all regions. Survival rates and cumulative survival in Mill Creek are the same because the reach length is $10 \mathrm{~km}$

\begin{tabular}{|c|c|c|c|}
\hline Year & Region & Survival Rates (SE) & Cumulative Survival (SE) \\
\hline \multirow[t]{4}{*}{2013} & Mill Creek & $0.78(0.03)$ & $0.78(0.03)$ \\
\hline & Upper River & $0.93(0.01)$ & $0.57(0.06)$ \\
\hline & Lower River & $0.96(0.01)$ & $0.42(0.07)$ \\
\hline & All & & $0.17(0.05)$ \\
\hline \multirow[t]{4}{*}{2014} & Mill Creek & $0.65(0.05)$ & $0.65(0.05)$ \\
\hline & Upper River & $0.87(0.02)$ & $0.32(0.07)$ \\
\hline & Lower River & $0.93(0.03)$ & $0.18(0.07)$ \\
\hline & All & & $0.03(0.03)$ \\
\hline \multirow[t]{4}{*}{2015} & Mill Creek & $0.62(0.03)$ & $0.62(0.03)$ \\
\hline & Upper River & $0.86(0.01)$ & $0.28(0.04)$ \\
\hline & Lower River & $0.92(0.02)$ & $0.15(0.05)$ \\
\hline & All & & $0.05(0.02)$ \\
\hline \multirow[t]{4}{*}{2016} & Mill Creek & $0.67(0.07)$ & $0.67(0.07)$ \\
\hline & Upper River & 0.00 & 0.00 \\
\hline & Lower River & 0.00 & 0.00 \\
\hline & All & 0.00 & 0.00 \\
\hline \multirow[t]{4}{*}{2017} & Mill Creek & $0.88(0.03)$ & $0.88(0.03)$ \\
\hline & Upper River & $0.97(0.01)$ & $0.73(0.06)$ \\
\hline & Lower River & $0.98(0.01)$ & $0.61(0.08)$ \\
\hline & All & & $0.42(0.09)$ \\
\hline
\end{tabular}

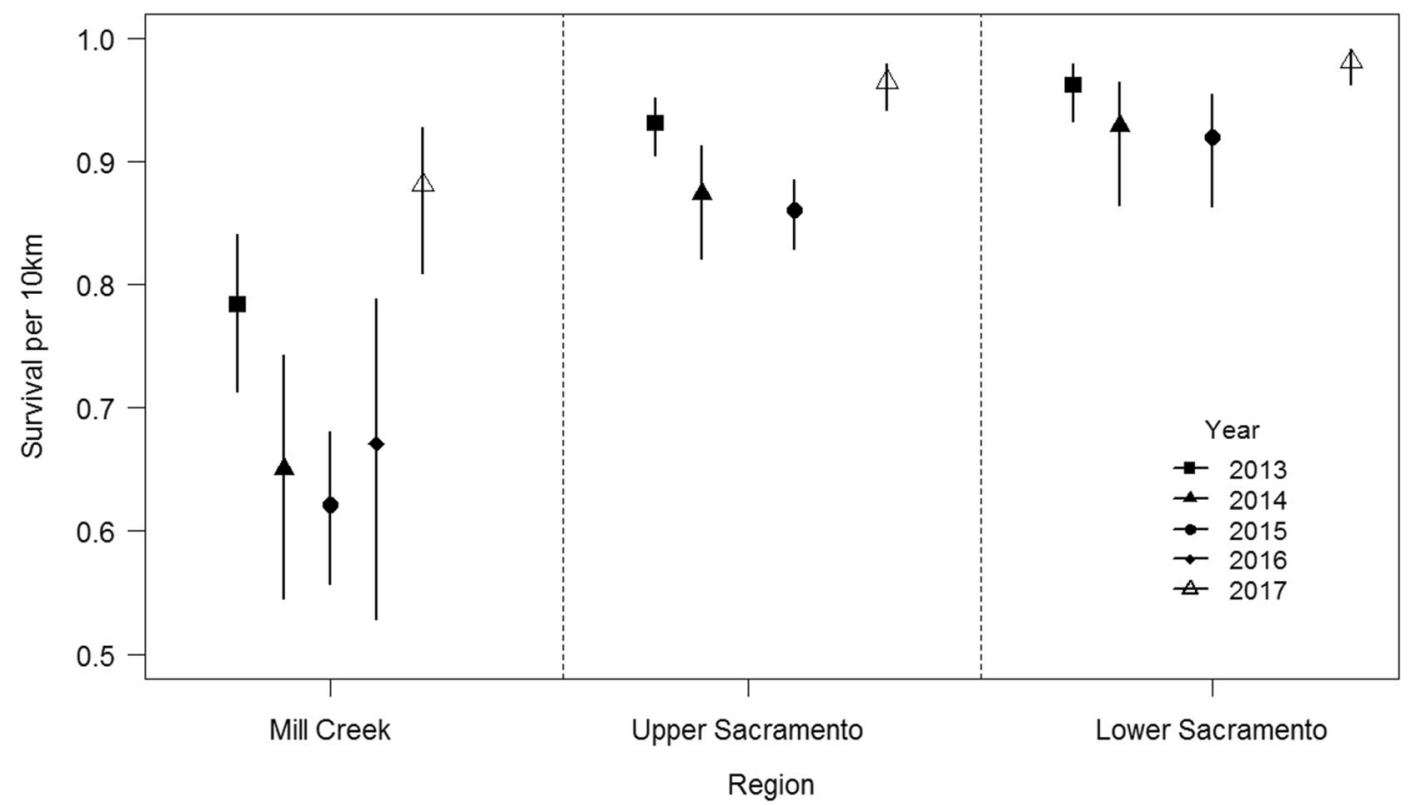

Fig. 3 Standardized regional survival rates (per $10 \mathrm{~km}$ ) for each region during all study years. Error bars represent the upper and lower $95 \%$ confidence intervals. In 2016 no tagged smolts survived through the upper and lower Sacramento River 
Fig. 4 Standardized survival rates (per $10 \mathrm{~km}$ ) averaged across all five years for each study reach. The dotted lines represent breaks between each region (Mill Creek, upper Sacramento River, lower Sacramento River). Error bars represent upper and lower 95\% confidence intervals

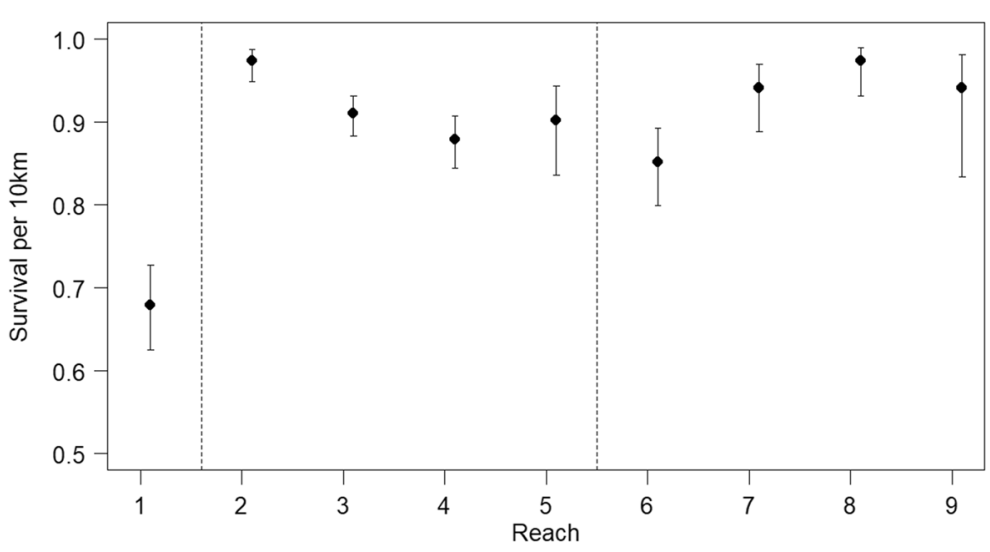

downstream reaches (reaches 3 to 6) with the lowest rates observed in the beginning of the lower Sacramento River (reach 6;85.2 \pm 2.3 ). Survival rates increased further downstream in the lower Sacramento River (reach $8 ; 97.4 \% \pm 1.3$ ) and remained relatively high through the end of the study region (reach $9 ; 94.2 \% \pm$ 3.3) (Fig. 4).

\section{Covariate survival}

In the regional analysis of survival as a function of individual and environmental covariates, the top two models suggest that flow in all regions (Mill Creek, upper Sacramento River, lower Sacramento River) as well as temperature in Mill Creek were a better model fit

Table 3 Beta estimates (standard errors) of covariates included in mark recapture models with a $\Delta \mathrm{AICc}<2$. The selected top models with the least parameters are in bold

\begin{tabular}{|c|c|c|c|c|c|c|c|c|c|c|c|c|}
\hline Covariate & Mode 1 & Model 2 & Model 3 & Model 4 & Model 5 & Model 6 & Model 7 & Model 8 & Model 9 & Model 10 & $\begin{array}{l}\text { Base } \\
\text { Model }\end{array}$ & $\begin{array}{l}\text { Null } \\
\text { Model }\end{array}$ \\
\hline Intercept & $\begin{array}{l}0.861 \\
(0.12)\end{array}$ & $\begin{array}{l}0.863 \\
(0.12)\end{array}$ & $\begin{array}{l}0.862 \\
(0.12)\end{array}$ & $\begin{array}{l}0.847 \\
(0.12)\end{array}$ & $\begin{array}{l}0.864 \\
(0.12)\end{array}$ & $\begin{array}{l}0.848 \\
(0.12)\end{array}$ & $\begin{array}{l}0.861 \\
(0.12)\end{array}$ & $\begin{array}{l}0.863 \\
(0.12)\end{array}$ & $\begin{array}{l}0.862 \\
(0.12)\end{array}$ & $\begin{array}{l}0.861 \\
(0.12)\end{array}$ & & \\
\hline Mill Creek & 0.406 & 0.278 & 0.4 & & 0.274 & & 0.406 & 0.278 & 0.4 & 0.406 & & \\
\hline Flow & $(0.17)$ & $(0.19)$ & $(0.17)$ & & $(0.19)$ & & $(0.17)$ & $(0.19)$ & $(0.17)$ & $(0.17)$ & & \\
\hline Mill Creek & & -0.2 & & -0.329 & -0.2 & -0.325 & & -0.2 & & & & \\
\hline Temp & & $(0.15)$ & & $(0.13)$ & $(0.15)$ & $(0.13)$ & & $(0.15)$ & & & & \\
\hline Upper Sac & 0.597 & 0.597 & 0.593 & 0.601 & 0.593 & 0.596 & 0.597 & 0.597 & 0.593 & 0.597 & & \\
\hline Flow & $(0.15)$ & $(0.15)$ & $(0.15)$ & $(0.15)$ & $(0.15)$ & $(0.15)$ & $(0.15)$ & $(0.15)$ & $(0.15)$ & $(0.15)$ & & \\
\hline Lower Sac & 0.763 & 0.763 & 0.767 & 0.763 & 0.767 & 0.767 & 0.652 & 0.652 & 0.664 & 0.82 & & \\
\hline Flow & $(0.25)$ & $(0.25)$ & $(0.24)$ & $(0.25)$ & $(0.24)$ & $(0.24)$ & $(0.25)$ & $(0.25)$ & $(0.25)$ & $(0.27)$ & & \\
\hline Lower Sac & & & & & & & -0.204 & -0.204 & -0.191 & & & \\
\hline Temp & & & & & & & $(0.23)$ & $(0.23)$ & $(0.22)$ & & & \\
\hline Lower Sac & & & & & & & & & & -0.096 & & \\
\hline Turbidity & & & & & & & & & & $(0.21)$ & & \\
\hline Fish Length & & & -0.103 & & -0.106 & -0.108 & & & -0.101 & & & \\
\hline$(\mathrm{mm})$ & & & $(0.08)$ & & $(0.08)$ & $(0.08)$ & & & $(0.08)$ & & & \\
\hline $\begin{array}{l}\text { Survival } \\
\quad \text { Covariates }\end{array}$ & 4 & 5 & 5 & 4 & 6 & 5 & 5 & 6 & 6 & 5 & 0 & 0 \\
\hline Parameters & 39 & 40 & 40 & 39 & 41 & 40 & 40 & 41 & 41 & 40 & 36 & 31 \\
\hline$\Delta \mathrm{AICc}$ & $\mathbf{0}$ & 0.39 & 0.49 & 0.75 & 0.83 & 1.16 & 1.36 & 1.75 & 1.94 & 1.98 & 35.8 & 135.2 \\
\hline
\end{tabular}


than the null model (constant survival) and base model (reach). These models were among the 10 best supported models $<2 \triangle \mathrm{AICc}$ points, and contained the least number of parameters (Table 3). Model averaging was used to compute standardized beta coefficients for each model, revealing the importance of flow and temperature in smolt survival. Increasing flow in all regions was correlated with higher survival rates through those regions, and increasing water temperature in Mill Creek was correlated with lower survival rates through Mill Creek (Fig. 5).

To explore the relationship between fish movement speed and reach-specific survival, survival rates were transformed using a logit link function and plotted
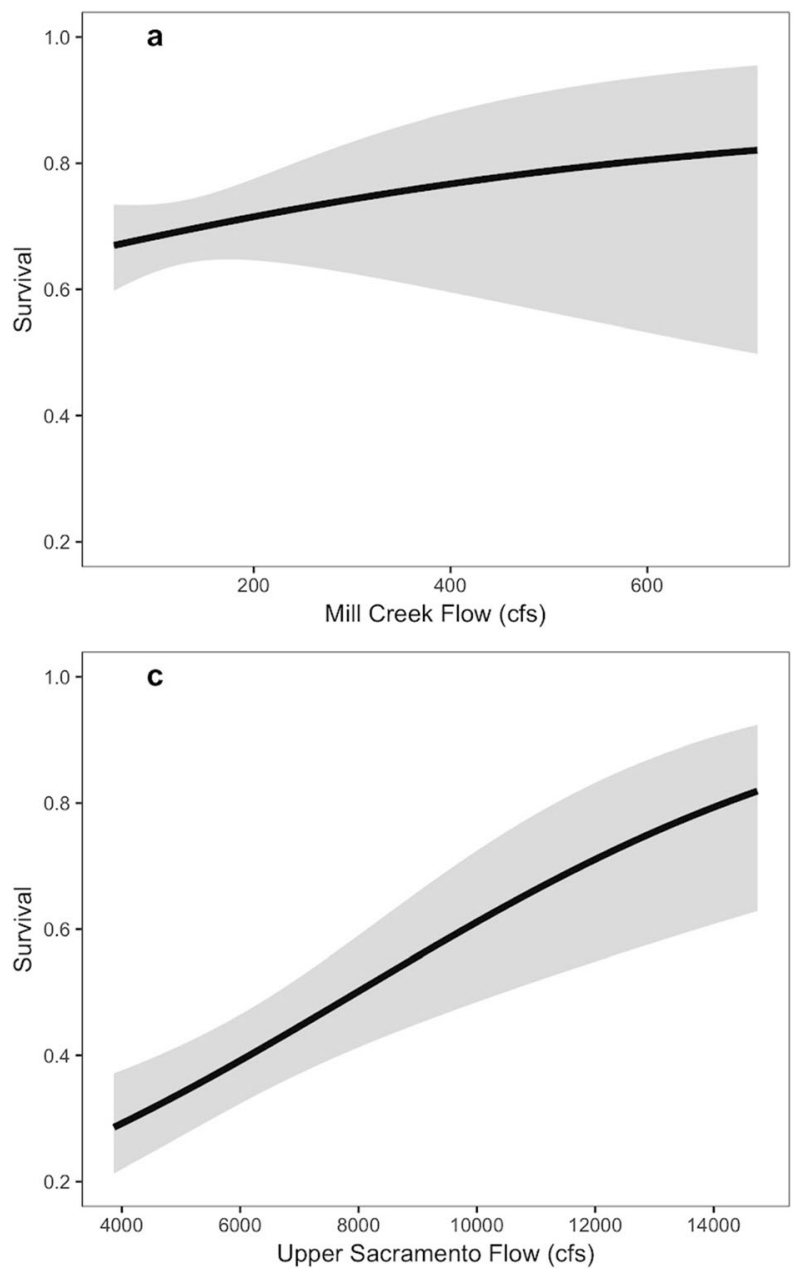

Fig. 5 Predicted survival through Mill Creek (a, b), the upper Sacramento River (c) and lower Sacramento River (d) in relation to flow and temperature values recorded during the study. Survival predictions were plotted using model averaged estimates from the against movement speed at each receiver location per year. Fish movement speeds were correlated with survival rates in all reaches (pseudo $\mathrm{R}^{2}$ value $=0.66$ ), with slower movement speeds correlated with lower survival rates and faster movement speeds correlated with higher survival rates (Fig. 6). The slowest movement speeds were observed in Mill Creek (16.3 km/day \pm 14.7 S.D), followed by the highest movement speeds in the first upper Sacramento River reach (70 km/day \pm 16 S.D), and the slowest movement speeds in reach 4 of the upper Sacramento River (49.6 km/day \pm 11.6 S.D). Movement speeds increased below reach 6 in the lower Sacramento River, and obtained a maximum in reach 8 in the lower Sacramento River (81 km/day \pm 7 S.D).
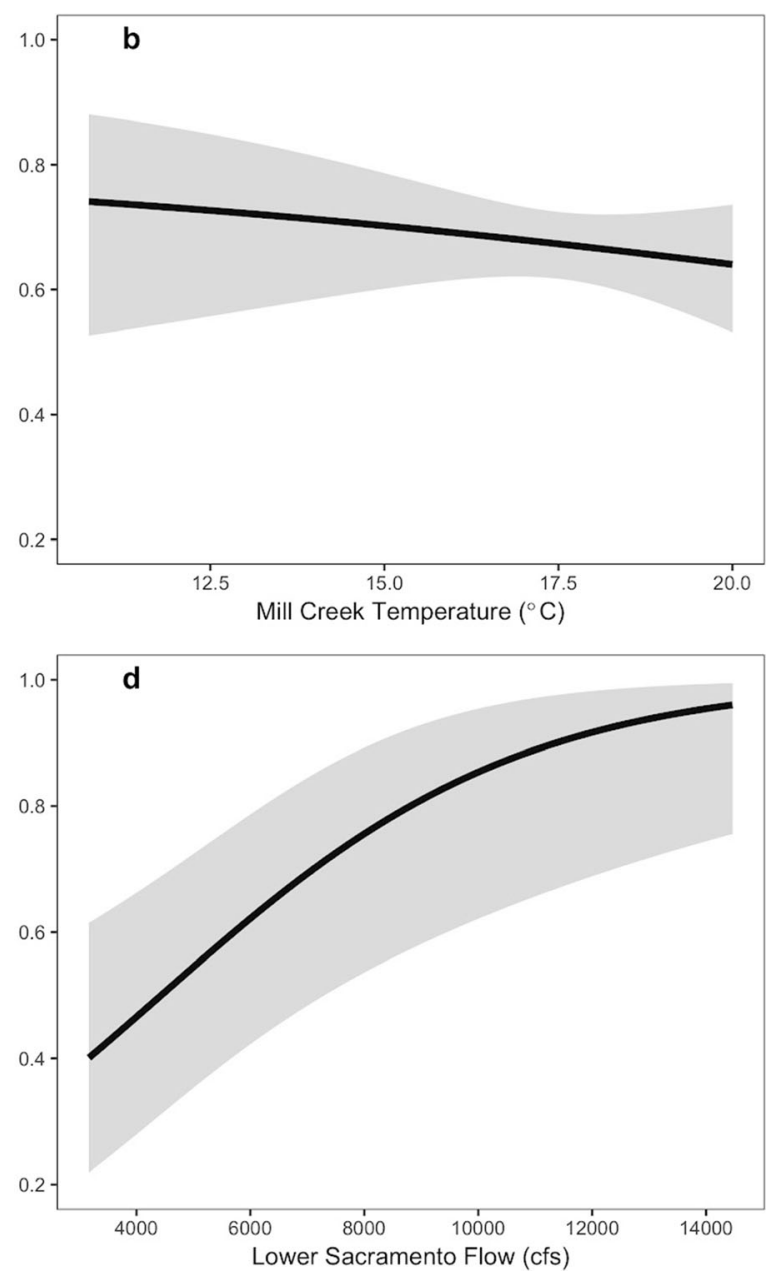

top two covariate models, and back transformed using the logit link function which constrains survival between 0 and 1 . Shaded areas represent the $95 \%$ confidence intervals around the survival estimates 


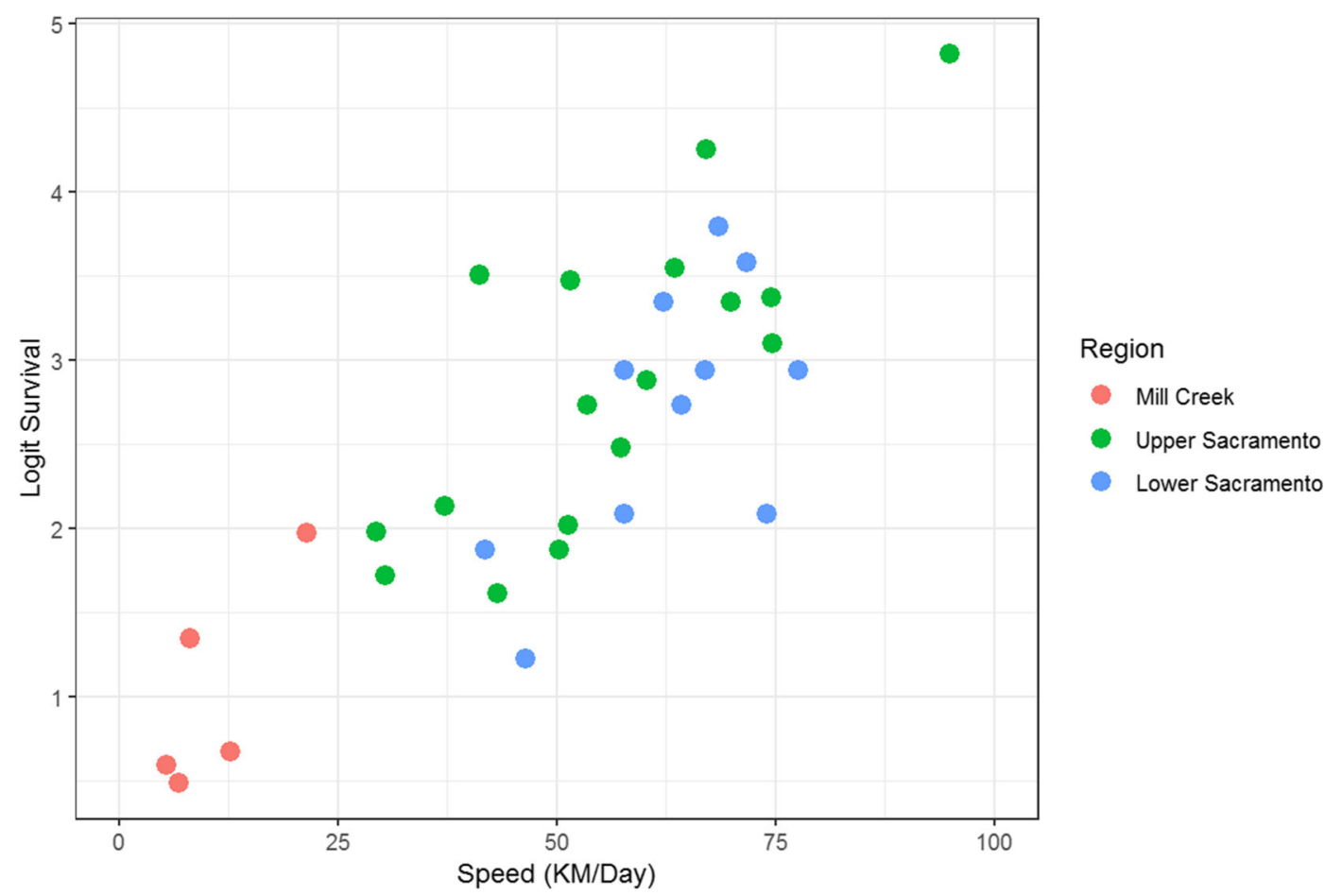

Fig. 6 Standardized reach specific survival rates transformed using a logit link function plotted against movement speed (kilometers per day). The points represent specific reaches within each

\section{Discussion}

This study provides the first estimates of wild spring-run Chinook salmon smolt survival through Mill Creek and the Sacramento River during the spring, encompassing both critically dry and wet years. Overall survival estimates were relatively low compared to other telemetry studies conducted in the Sacramento River (Michel et al. 2015; Cordoleani et al. 2018), and were most likely influenced by three consecutive years of drought during the study. Flows in Mill Creek during the drought years $(2013,2014,2015)$ were considerably lower and water temperatures higher than the 20 year average (Fig. 2). In addition, Sacramento River flows in the drought years were considerably lower than the 20 year average, and remained low in 2016 when flow conditions improved in Mill Creek. Flows in Mill Creek and the Sacramento River were well above the 20 year average in the 2017 outmigration period when California experienced its wettest winter and spring on record, and 2017 had the highest outmigration survival rates observed during this study through all regions (Fig. 3).

Fish tagged during this study were relatively large compared to the mean size of juveniles captured in the region where fish survived to allow for movement and survival estimates to be calculated. (beta regression, pseudo $R^{2}$ value $=$ 0.66)

Mill Creek RST, but coincided with peak juvenile outmigration timing (Johnson and Merrick 2012). While smolts make up a small proportion of the overall catch, studies have shown they can have outsized contributions to adult spawning populations in some years (Sturrock et al. 2015). During dry years, warmer than average conditions lead to elevated stream temperature which results in higher growth rates and early onset of smoltification (Beckman et al. 1998). During the drought year of 2015 this was found to be true, with higher numbers of smolts captured earlier in the spring. However, during most years smolts rearing in Mill Creek take longer to grow and outmigrate compared to juveniles in other CCV streams (Whitton et al. 2011) due to the high elevation spawning and rearing habitat. This results in delayed outmigration timing that often coincides with increased water diversions, and likely creates unfavorable outmigration conditions.

Survival rates in Mill Creek were relatively low compared to reaches in the upper and lower Sacramento River. Overall, $68 \%$ of the 334 tagged smolts appeared to have survived their outmigration through the lower nine kilometers of Mill Creek and entered the Sacramento River. These survival estimates are influenced in 
large part by the spring of 2015 , when only $62 \%$ of the 186 smolts survived to the Sacramento River. During 2015, Mill Creek experienced extremely low flows resulting from the drought and an exceptionally low snowpack. The low flows were further exacerbated by agricultural water diversions which removed approximately $50 \%$ of the stream flow from lower Mill Creek. The remaining flow was insufficient for migrating salmon smolts, as suggested by the low survival rates in relation to stream flow in Mill Creek (Fig. 5).

Stream flow in rivers manipulated by agricultural practices can be a strong driver of smolt survival, as was documented on Idaho's Snake River where increased flows downstream of large dams resulted in higher survival rates for juvenile Chinook salmon migrating to the ocean (Connor et al. 2003). In the Sacramento River, flow was found to be the top covariate in predicting outmigration survival of hatchery late-fall Chinook salmon, with years of high flow resulting in a three-fold increase in outmigration survival through the river (Henderson et al. 2018; Friedman et al. 2019). In addition to flow, higher water velocities can lead to improved smolt survival rates, likely because it promotes rapid downstream migration which reduces the exposure time to predators (Tiffan et al. 2009). In the upper and lower Sacramento River, faster movement speeds were associated with higher survival rates during this study (Fig. 6), which is likely attributed to higher water velocities during periods of high flow which help move fish quickly through the system.

Conversely, during drought conditions low stream flows can negatively impact smolt movement speeds (Zabel et al. 1998; Smith et al. 2002). One potential explanation for the relatively low survival rates in Mill Creek compared to other reaches in the Sacramento River is the slower movement speeds observed there (Fig. 6). Movement rates were between 8 and $19 \mathrm{~km} \cdot \mathrm{day}^{-1}$ in Mill Creek compared to $40-$ $80 \mathrm{~km} \cdot \mathrm{day}^{-1}$ in the Sacramento River. The relatively slow smolt movement speeds through Mill Creek increases exposure time to potential risks such as predation and the effects of water diversions, which can both significantly impact survival; water diversions reduce flow and diminish cover, resulting in increased predator densities (Mussen et al. 2012). Movement rates improved in Mill Creek during years of higher flow (2016 and 2017), increasing from 8 to $10 \mathrm{~km} \cdot \mathrm{day}^{-1}$ to $>20 \mathrm{~km} \bullet$ day $^{-1}$, and corresponded with higher survival rates [ $62 \%$ in 2015 with exceptionally low flow (mean =
$72 \mathrm{cfs}$ ), and $88 \%$ in 2017 with high flow (mean $=620$ cfs)].

Drought conditions also result in elevated water temperature, which impairs smolt swimming performance (Lehman et al. 2017), and increases metabolic demand in predator fish, potentially leading to higher predation rates on juvenile Chinook salmon. Low flows resulting from drought conditions may also increase the likelihood of smolt encounters with predator fish, and clear water resulting from impaired run-off below large dams may increase the risk of predation on juvenile Chinook salmon (Gregory 1993). Additional compounding stressors include anthropogenic structures in Mill Creek and the Sacramento River such as water diversion infrastructure, bridge pilings, rock revetment, and wing dams which increase the effectiveness of ambush predators (Sabal et al. 2016). These structures create unnatural locations where predators can lie and wait, striking naïve juvenile salmon that are potentially disoriented after swimming through these obstacles, as they pass by (Brown and Moyle 1981; Sabal et al. 2016). Striped bass have been found to be effective ambush predators (Tucker et al. 2002) and are estimated to significantly impact juvenile Chinook salmon populations (Lindley and Mohr 2003). In addition, the long migration distances for Mill Creek smolts result in longer exposure times to predators, which may lead to significant mortality (Anderson et al. 2005).

California's variable climate can result in multiple years of drought followed by exceptional rainfall. This occurred during the 2017 water year, when California experienced unprecedented rainfall, elevating stream flows in all, and flooding in some, CCV rivers. The high flows resulted in favorable conditions for out-migrating smolts, and survival rates in the Sacramento River greatly improved compared to the previous four years of the study (Fig. 3). In total, $42.3 \%( \pm 9.1)$ of the smolts tagged in Mill Creek survived through the Sacramento River in 2017, increasing from an average survival of $9.9 \%( \pm 3.2)$ during the previous four study years (20132016). A similar increase in survival was observed in hatchery late fall-run Chinook salmon smolts across dry and wet years in the Sacramento River, when 3\% survived to the Golden Gate during years of relatively low flow (2007-2010), followed by an increase in survival to $15 \%$ during a wet year with high river flows (2011) (Michel et al. 2015). While these high spring flow 
events are relatively uncommon in the regulated CCV system, they significantly increase survival rates of outmigrating salmon smolts.

The results from this study have implications for future restoration and management actions for threatened and endangered populations of wild Chinook salmon in the CCV. Smolts that out-migrate relatively late in the spring experienced very low survival rates during years of low flows, most likely as a result of flow-mediated predation during drought conditions (2013-2015) and substantial water diversions in the Sacramento River (2013-2016). Survival decreased with lower flows and higher water temperatures, and during drought conditions a large proportion of smolts perished within Mill Creek or shortly after migrating into the Sacramento River. Supplying enough water instream for smolts during their critical migration window can lead to higher outmigration survival, as well as increased returns of spawning adults (Raymond 1968; Berggren and Filardo 1993; Giorgi et al. 1997; Michel 2018). To accomplish this goal, managers need to consider trade-offs between stream flows for agriculture and fisheries needs, with an emphasis on maintaining adequate stream flows during critical stages of the salmon life cycle. Further, there are additional benefits from synchronizing managed flow increases on the Sacramento River with natural flow events occurring in the natal tributaries. As the few wild salmon populations in the $\mathrm{CCV}$ remain threatened and endangered, understanding how habitat and environmental conditions influence their survival is critical to support effective recovery planning.

Acknowledgements This project would not have been possible without funding from U.S Fish and Wildlife Service's Anadromous Fish Restoration Program (AFRP) grant \#F12PG00194. Special thanks are extended to Nate Mantua of NOAA Fisheries for his help editing this manuscript and providing insightful feedback, to Chris Edwards of UC Santa Cruz for his guidance with the statistical modeling, Sara John of UC Santa Cruz for her help with GIS and creating maps, and to Sean Hayes for obtaining funding and helping with initial study design. Help with fish collection was provided by staff from Red Bluff CDFW, and land access was granted by the Nature Conservancy Gray Davis Dye Creek Preserve, and Darrel Mullins of the Los Molinos Mutual Water Company. All fish were handled humanely according to the methods described in NOAA IACUC permit \# DANNE1905. Any use of trade, firm, or product names is for descriptive purposes only and does not imply endorsement by the U.S. Government.
Open Access This article is licensed under a Creative Commons Attribution 4.0 International License, which permits use, sharing, adaptation, distribution and reproduction in any medium or format, as long as you give appropriate credit to the original author(s) and the source, provide a link to the Creative Commons licence, and indicate if changes were made. The images or other third party material in this article are included in the article's Creative Commons licence, unless indicated otherwise in a credit line to the material. If material is not included in the article's Creative Commons licence and your intended use is not permitted by statutory regulation or exceeds the permitted use, you will need to obtain permission directly from the copyright holder. To view a copy of this licence, visit http://creativecommons.org/licenses/by/4.0/.

\section{References}

Akaike H (1981) Likelihood of a model and information criteria. J Econ 16:3-14. https://doi.org/10.1016/0304-4076(81 )90071-3

Ammann AJ, Michel CJ, MacFarlane RB (2013) The effects of surgically implanted acoustic transmitters on laboratory growth, survival and tag retention in hatchery yearling Chinook salmon. Environ Biol Fish 96:135-143. https://doi.org/10.1007/s10641-011-9941-9

Anderson JJ, Gurarie E, Zabel RW (2005) Mean free-path length theory of predator-prey interactions: Application to juvenile salmon migration. Ecol Model 186:196-211

Baker PF, Speed TP, Ligon FK (1995) Estimating the influence of temperature on the survival of Chinook salmon smolts(Oncorhynchus tshawytscha) migrating through the Sacramento- San Joaquin River Delta of California. Can J Fish Aquat Sci 52:855-863

Becker CD (1971) Temperature timing and seaward migration of juvenile chinook salmon from the central columbia river. Government Reports Announcements 71:48

Beckman BR, Larsen DA, Lee-Pawlak B, Dickhoff WW (1998) Relation of fish size and growth rate to migration of spring Chinook salmon smolts. N Am J Fish Manag 18(3):537-546

Berggren TJ, Filardo MJ (1993) An analysis of variables influencing the migration of juvenile Salmonids in the Columbia River basin north. American journal of fisheries management 13:48-63. https://doi.org/10.1577/1548-8675(1993)013 $<0048$ :AAOVIT>2.3.CO;2

Bradford MJ (1995) Comparative review of Pacific salmon survival rates. Can J Fish Aquat Sci 52:1327-1338. https://doi. org/10.1139/195-129

Brandes PL, McLain JS (2001) Juvenile Chinook salmon abundance, distribution, and survival in the Sacramento-San Joaquin estuary. In: Brown LR (ed) Contributions to the biology of Central Valley Salmonids, vol 2. Fish bulletin, vol 179. California Department of Fish and Game, Sacramento, California, pp 39-138

Brown LR, Moyle PB (1981) The impact of squawfish on salmonid populations north. American journal of fisheries management 1:104-111. https://doi.org/10.1577/1548-8659(1981 ) $1<104$ :TIOSOS $>2.0$.CO;2

Brown RS, Harnish RA, Carter KM, Boyd JW, Deters KA, Eppard MB (2010) An Evaluation of the Maximum Tag Burden for 
Implantation of Acoustic Transmitters in Juvenile Chinook Salmon North American. Journal of Fisheries Management 30:499-505. https://doi.org/10.1577/M09-038.1

Buchanan RA, Skalski JR, Brandes PL, Fuller A (2013) Route Use and Survival of Juvenile Chinook Salmon through the San Joaquin River Delta. N Am J Fish Manag 33:216-229. https://doi.org/10.1080/02755947.2012.728178

Burnham KP, Anderson DR (2002) Model selection and multimodel inference: a pratical information-theoretic approach. 2nd edition edn. Springer-Verlag, New York, New York, USA

Cavallo B, Merz J, Setka J (2012) Effects of predator and flow manipulation on Chinook salmon (Oncorhynchus tshawytscha) survival in an imperiled estuary. Environ Biol Fish:1-11. https://doi.org/10.1007/s10641-012-9993-5

Clark TD et al (2016) Tracking wild sockeye salmon smolts to the ocean reveals distinct regions of nocturnal movement and high mortality. Ecol Appl. https://doi.org/10.1002/15-0632

Connor WP, Burge HL, Yearsley JR, Bjornn TC (2003) Influence of flow and temperature on survival of wild subyearling fall Chinook Salmon in the Snake River north. American journal of fisheries management 23:362-375. https://doi. org/10.1577/1548-8675(2003)023<0362:IOFATO >2.0. $\mathrm{CO} ; 2$

Cordoleani F, Notch J, McHuron AS, Ammann AJ, Michel CJ (2018) Movement and Survival of Wild Chinook Salmon Smolts from Butte Creek During Their Out-Migration to the Ocean: Comparison of a Dry Year versus a Wet Year. Trans Am Fish Soc 147:171-184

Cormack RM (1964) Estimates of survival from the sighting of marked animals. Biometrika 51:429-438

Deters KA, Brown RS, Carter KM, Boyd JW, Eppard MB, Seaburg AG (2010) Performance assessment of suture type, water temperature, and surgeon skill in juvenile Chinook salmon surgically implanted with acoustic transmitters. Trans Am Fish Soc 139:888-899

Friedman WR, Martin BT, Wells BK, Warzybok P, Michel CJ, Danner EM, Lindley ST (2019) Modeling composite effects of marine and freshwater processes on migratory species. Ecosphere 10:e02743

Giorgi AE, Hillman T, Stevenson JS, Hays SG, Peven CM (1997) Factors that influence the downstream migration rates of juvenile salmon and steelhead through the hydroelectric system in the mid-Columbia River basin. N Am J Fish Manag 17:268-282

Gregory RS (1993) Effect of turbidity on the predator avoidance behavior of juvenile Chinook salmon (Oncorhynchus tshawytscha). Can J Fish Aquat Sci 50:241-246

Gregory RS, Levings CD (1998) Turbidity reduces predation on migrating juvenile Pacific salmon. Trans Am Fish Soc 127: 275-285

Grossman GD (2016) Predation on Fishes in the Sacramento-San Joaquin Delta: Current Knowledge and Future Directions San Francisco Estuary and Watershed Science 14

Healey MC (1991) Pacific Salmon life histories in: Margolis CGaL (ed). University of British Columbia Press, Vancouver, pp 312-230

Henderson MJ, Iglesias IS, Michel CJ, Ammann AJ, Huff DD (2018) Estimating spatial-temporal differences in Chinook salmon outmigration survival with habitat and predation related covariates. Can J Fish Aquat Sci. https://doi. org/10.1139/cjfas-2018-0212

Johnson M, Merrick K (2012) Juvenile salmonid monitoring using rotary screw traps in deer creek and Mill Creek, Tehama County, California from 1994 through 2010. A Summary Report

Jolly GM (1965) Explicit estimates from capture-recapture data with both death and immigration-stochastic model. Biometrika 52:225-247

Laake J, Rexstad E (2013) RMark-an alternative approach to building linear models in MARK

Lebreton J-D, Burnham KP, Clobert J, Anderson DR (1992) Modeling Survival and Testing Biological Hypotheses Using Marked Animals: A Unified Approach with Case Studies. Ecol Monogr 62:67-118

Lehman B, Huff DD, Hayes SA, Lindley ST (2017) Relationships between Chinook Salmon swimming performance and water quality in the San Joaquin River. California Transactions of the American Fisheries Society 146:349-358

Lindley ST, Mohr MS (2003) Modeling the effect of striped bass (Morone saxatilis) on the population viability of Sacramento River winter-run Chinook salmon (Oncorhynchus tshawytscha). Fish Bull 101:321-331

McMichael GA et al (2010) The Juvenile Salmon Acoustic Telemetry System: A New Tool. Fisheries 35:9-22. https://doi.org/10.1577/1548-8446-35.1.9

Michel CJ (2018) Decoupling outmigration from marine survival indicates outsized influence of streamflow on cohort success for California's Chinook salmon populations Canadian journal of fisheries and aquatic sciences

Michel CJ et al (2015) Chinook salmon outmigration survival in wet and dry years in California's Sacramento River. Can J Fish Aquat Sci 72:1749-1759. https://doi.org/10.1139/cjfas2014-0528

Moyle PB, Crain PK, Whitener K (2007) Patterns in the use of a restored California floodplain by native and alien fishes San Francisco Estuary and Watershed Science 5

Munsch SH, Greene CM, Johnson RC, Satterthwaite WH, Imaki $\mathrm{H}$, Brandes PL (2019) Warm, dry winters truncate timing and size distribution of seaward-migrating salmon across a large, regulated watershed ecological applications: 01880

Mussen TD et al (2012) Assessing juvenile Chinook Salmon behavior and entrainment risk near unscreened water diversions: large flume simulations. Trans Am Fish Soc 142:130 142. https://doi.org/10.1080/00028487.2012.720633

NMFS NMFS (2014) Recovery Plan for the Evolutionarily Significant Units of Sacramento River Winter-run Chinook Salmon and Central Valley Spring-run ChinookSalmon and the Distinct Population Segment ofCalifornia Central Valley Steelhead. https://www.westcoast.fisheries.noaa. gov/publications/recovery_planning/salmon_ steelhead/domains/california_central_valley/final_recovery_ plan_07-11-2014.pdf

Nobriga $\bar{M}$ (2007) Shallow-Water Piscivore-Prey Dynamics in California's Sacramento-San Joaquin Delta. Science 5

Notch J (2017) Out-migration survival of wild Chinook Salmon (Oncorhynchus tshawytscha) smolts from Mill Creek through the Sacramento River during drought conditions. University of California, Santa Cruz

Powell LA (2007) Approximating variance of demographic parameters using the Delta method: a reference for avian 
biologists. Condor 109(4):949-954. https://doi.org/10.1093 /condor/109.4.949

R Core Team. 2016. R: a language and environment for statistical computing. R Foundation for Statistical Computing, Vienna. Available: https://www.R-project.org/. Accessed Aug 2018

Raymond HL (1968) Migration Rates of Yearling Chinook Salmon in Relation to Flows and Impoundments in the Columbia and Snake Rivers. Trans Am Fish Soc 97:356359. https://doi.org/10.1577/1548-8659(1968)97[356 :MROYCS]2.0.CO;2

Rechisky EL, Welch DW, Porter AD, Jacobs-Scott MC, Winchell PM, McKern JL (2012) Estuarine and early-marine survival of transported and in-river migrant Snake River spring Chinook salmon smolts Sci rep 2 doi:http:// www.nature.com/srep/2012/120611/srep00448/abs/ srep00448.html\#supplementary-information

Sabal M, Hayes S, Merz J, Setka J (2016) Habitat alterations and a nonnative predator, the striped bass, Increase Native Chinook Salmon Mortality in the Central Valley, California. N Am J Fish Manag 36:309-320

Seber GA (1982) The estimation of animal abundance and related parameters, 2nd edn. Chapman, London and Macmillan

Singer GP et al (2019) Behavioral response of juvenile Chinook Salmon to surgical implantation of micro-acoustic transmitters. Trans Am Fish Soc 148(2):480-492

Smith SG, Muir WD, Williams JG, Skalski JR (2002) Factors associated with travel time and survival of migrant yearling chinook salmon and steelhead in the lower Snake River. N Am J Fish Manag 22:385-405

Sommer TR, Nobriga ML, Harrell WC, Batham W, Kimmerer WJ (2001) Floodplain rearing of juvenile chinook salmon: evidence of enhanced growth and survival. Can J Fish Aquat Sci 58:325-333

Sturrock AM, Wikert JD, Heyne T, Mesick C, Hubbard AE, Hinkelman TM, Weber PK, Whitman GE, Glessner JJ, Johnson RC (2015) Reconstructing the migratory behavior and long-term survivorship of juvenile Chinook Salmon under contrasting hydrologic regimes. PLoS One 10(5): e0122380. https://doi.org/10.1371/journal.pone.0122380

Sturrock AM, et al. (2019) Eight decades of hatchery Salmon releases in the California Central Valley: factors influencing straying and resilience. Fisheries

SWRCB (2017) Scientific Basis Report in Support of New and Modified Requirements for Inflows from the Sacramento River and its Tributaries and Eastside Tributaries to the Delta, Delta Outflows, Cold Water Habitat, and Interior Delta Flows

Sykes GE, Johnson CJ, Shrimpton JM (2009) Temperature and Flow Effects on Migration Timing of Chinook Salmon
Smolts. Trans Am Fish Soc 138:1252-1265. https://doi. org/10.1577/T08-180.1

Tiffan KF, Kock TJ, Haskell CA, Connor WP, Steinhorst RK (2009) Water velocity, Turbulence, and Migration Rate of Subyearling Fall Chinook Salmon in the Free-Flowing and Impounded Snake River. Trans Am Fish Soc 138:373-384. https://doi.org/10.1577/t08-051.1

Tucker ME, Martin CD and Gaines PD (2002) Spatial and Temporal Distribution of Sacramento Pikeminnow and Striped Bass at the Red Bluff Diversion Complex, Including the Research Pumping Plant, Sacramento River, California: January, 1997 to August, 1998 Red Bluff Research Pumping Plant Report Series 10

Welch DW et al (2008) Survival of migrating Salmon Smolts in large Rivers with and without dams. PLoS Biol 6:21012108. https://doi.org/10.1371/journal.pbio.0060265

White GC, Burnham KP (1999) Program MARK: survival estimation from populations of marked animals. Bird Study 46: 120-139

Whitton, K. S., D. J. Colby, J. M. Newton, and M. R. Brown. 2011. Juvenile salmonid monitoring in Battle Creek, California, November 2009 through July 2010. USFWS Report. U.S. Fish and Wildlife Service, Red Bluff Fish and Wildlife Office, Red Bluff, California

Williams TH et al. (2016) Viability assessment for Pacific salmon and steelhead listed under the endangered species act: southwest

Yates D et al (2008) Climate warming, water storage, and Chinook salmon in California's Sacramento Valley. Clim Chang 91: 335-350. https://doi.org/10.1007/s10584-008-9427-8

Yoshiyama RM, Fisher FW, Moyle PB (1998) Historical Abundance and Decline of Chinook Salmon in the Central Valley Region of California. N Am J Fish Manag 18:487521

Yoshiyama RM, Gerstung ER, Fisher FW, Moyle PB (2001) Historical and present distribution of Chinook salmon in the Central Valley drainage of California. In: Brown RL (ed) Contributions to the biology of Central Valley Salmonids, Fish bulletin, vol 179, vol 1. California Department of Fish and Game, Sacramento, pp 71-176

Zabel RW, Anderson JJ, Shaw PA (1998) A multiple-reach model describing the migratory behavior of Snake River yearling chinook salmon (Oncorhynchus tshawytscha). Can J Fish Aquat Sci 55:658-667

Publisher's note Springer Nature remains neutral with regard to jurisdictional claims in published maps and institutional affiliations. 